\title{
Folk-Lore from the Himalayas.
}

\section{H. W. Emerson}

To cite this article: H. W. Emerson (1917) Folk-Lore from the Himalayas., Folklore, 28:3, 323-325, DOI: 10.1080/0015587X.1917.9718997

To link to this article: http://dx.doi.org/10.1080/0015587X.1917.9718997

$$
\text { 曲 Published online: } 01 \text { Feb } 2012 .
$$

Submit your article to this journal $\sqsubset$

Q View related articles $₫$ 
thought she would raise chickens on her own account, and accordingly she set a few hens on eggs. Some few weeks later, I asked if the chickens were doing well, and she told me none had hatched out, adding that the old women on the farm had asked her how she could expect them to do so, seeing that she herself had hopes of becoming a mother at some rather distant date. I could not account for this, to me, quite new idea, but I always hoped to find some day an explanation of it. This I never did find till in reading Golden Bough ("The Magic Art," vol. i. p. Ir4) I found there was an idea prevalent among certain peoples or tribes that an influence benign or malignant might be exercised by an expectant mother. I then asked one of my old Gaelic-speaking servants if they knew of the existence of any such fancies in the district, and she said "Yes," that the old people would be saying "that if a woman set a hen on eggs under these circumstances, either the eggs would hatch out, and the expected child would die before birth, or if all went well with the child, the eggs would certainly prove unfertile.

Alice Fowler.

Folk-Lore from the Himalayas.

The Waking of a God.

THE Phăg festival takes place at the full moon of the month of Phāgun (February-March), and corresponds with the Hindu celebrations of the Holi. ${ }^{1}$ The five deities hibernate during the winter months, going to sleep when snow commences to fall and not waking up again until their worshippers arouse them. The awakening takes place at the Phãg festival, and, although the rejoicings are often premature, they are intended to celebrate the advent of spring and the passing of winter. Each temple has a small window let into an outer wall of the second storey, and opening into the chamber where the images of the god are kept. A miniature image is placed below the window inside the room. A day or two previous to the full moon, two sides are chosen from the god's subjects, each consisting of from eight to eleven men. One party represents the god's defenders, the other his awakeners; but

' Folk-Lore, xxv. p. 55 et sey. 
the members of both have to prepare themselves for their sacred duties by fasting until the appointed day arrives. On that day they arm themselves with snowballs, the snow being brought from the hills above, should none be lying round the homestead. The assailants take up a position about twenty paces from the temple, whilst the rest station themselves below the window. All hold their snowballs ready in the skirts of their long coats, and at a given signal the battle begins; but whereas the supporters of the god pelt his adversaries, the latter aim at the open window. Should no missile fall into the room before the ammunition is exhausted, the throwers have to pay a fine of several rams, for their indifferent markmanship has defeated the object of the fight. The god sleeps on, unconscious of the efforts made to break his slumbers, and other ways must be adopted to rouse him from his lethargy. Men creep up the staircase, carrying trumpets and conchshells, and when all are ready blow a mighty blast in unison. Others bang the doors and rattle its massive chains, shouting to the god to bestir himself. But, at best, this is an unsatisfactory way of bringing the god to life, as distasteful to the victim as to his worshippers. The god dislikes having his privacy disturbed by an unseemly din outside his chamber; he prefers to wake as the pure snow strikes his face, cold and rude though the awakening be. And so, if the throwers succeed-as they usually do-in placing a ball through the window, the omen is considered most auspicious. They then dance and leap with joy, shouting that the god has risen from his couch. The fidei-defensores, however, pretend to be horror-stricken at the sacrilege; and the culprits have to flee under a running fire of abuse, snow, clods, stones, and even gun-shots. The chase continues through and round the village, until at length a truce is called. Both sides agree to abide by the decision of the god. His spirit, refreshed and strengthened by the winter's sleep, descends upon his diviner, who expounds the sittiation to his master and interprets the divine reply. This is always to the same effect. The deity commends his supporters for their efforts on his behalf; but he also thanks. his assailants for their kindly thought in rousing him, now that the time of winter cold has passed and the season of spring time is at hand. Thus comforted, the worshippers prepare to listen to the 
programme of the coming year, for the announcement of harvest prospects, as well as of prophecies of a general kind, is a feature of the festival. The confederacy of the five gods exercises jurisdiction in a subdivision of the Bashahr State, one of the Simla Hill States in the Punjab. Their worshippers belong to the Kuran subdivision of the Kanet tribe. The five gods are sometimes known as the Pānch Nāg, or five serpent deities; four of them are certainly serpent deities; the fifth is uncertain. Much information on the Nāga cult in this region will be found in The Sun and the Serpent, by C. F. Oldham, London, 1905.

H. IV. EMErson.

Notes on Lincolnshire Folk-Lore.

Hedgehogs.

(Folk-Lore, xxviii. No. I. p. 101).

THE belief that hedgehogs suck the milk of cows is common in Lincolnshire. Probably it occurs in all English counties.

Is it mere folk-lore, or not?

It is difficult to see how the muzzle of a hedgehog can draw milk from a cow, yet the following incident shows that some cows do object to hedgehogs.

Twenty years ago, or rather more, when I happened to be visiting my brother, the vicar of Cadney, Lincolnshire, I went into a field in which several cows were grazing quietly enough. They paid little attention to me as I passed by, but when I returned, carrying a hedgehog, to show to my little nephew, the formerly placid animals rushed wildly to and fro. Evidently the sight of "Master Prickles" upset their nerves.

So far as I remember, I have not met anyone who had come on hedgehogs sucking, but one or two of my acquaintances have seen them under suspicious circumstances, and many people assert that they have friends who have observed "the prickly otchin" drawing milk. There is a story here, in Kirton-in-Lindsey, of a certain farmer who noticing that his cows did not yield enough milk watched for the culprit, or culprits, and convicted hedgehogs of 